\title{
Hyperinsulinemia and Cardiovascular Risk Factors in Stroke Patients
}

\author{
Paulus Wiyono, Poerwono Rahardjo, I Gde Raka Widiana, Purnama
}

\begin{abstract}
Abstrak
Telah dilakukan studi kasus kelola di Unit Rawat Jalan Bagian Neurologi RSUP DR Sardjito Yogyakarta, indonesia. Penelitian ini bertujuan untuk menentukan adanya hiperinsulinemia pada penderita strok tanpa disertai diabetes melitus. Penderita yang dimasukkan ke dalam penelitian ini adalah penderita strok yang hidup sedikit-dikitnya 3 bulan setelah serangan. Kelola dipilih dari penderita bukan strok di Unit yang sama dengan penyeimbangan jenis kelamin dan umur. Selama penelitian 51 penderita strok (39 L, 12 P, berumur 58,73 $\pm 10,37$ tahun) dan 51 kelola ( 39 L, 12 P, berumur 58,67 $\pm 9,97$ tahun) dimasukkan ke dalam penelitian. Tidak dijumpai perbedaan bermakna pada indeks massa tubuh, merokok dan kadar lipid kecuali kolesterol-HDL antara kasus dan kelola. Kadar kolesterol-HDL lebih rendah bermakna $(46,69 \pm 16,05$ vs 53,67 $\pm 23,26 \mathrm{mg} / \mathrm{dl}, \mathrm{p}<0,05)$ dan tekanan darah lebih ting gi bermakna

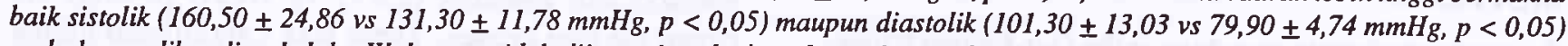
pada kasus dibanding kelola. Walaupun tidak dijumpai perbedaan bermakna pada kadar insulin puasa $(9,28 \pm 2,74 \mathrm{vs} 8,38 \pm 2,69$ $\mu U / \mathrm{ml}, p>0,05)$, namun dijumpai kadar insulin pasca-makan lebih tinggi bermakna $(94,89 \pm 12,15$ vs $55,21 \pm 6,88 \mu U / \mathrm{ml}, p<0,05)$ pada kasus dibanding kelola. Walaupun tidak dijumpai perbedaan bermakna dari kadar insulin puasa baik pada subkelompok TGN (toleransi glukose normal) dan TGT (toleransi glukosa terganggu), $p<0,05$, namun dijumpai kadar insulin pasca makan lebih tinggi bermakna baik pada subkelompok TGN $(98,15 \pm 14,97$ vs 38,76 $\pm 6,62 \mu \mathrm{U} / \mathrm{ml}, \mathrm{p}<0,05)$ dan TGT $(89,85 \pm 20,98$ vs 75,24 $\pm 11,82$ $\mu U / m l, p<0,05)$ pada kelompok kasus dibanding kelola. Dijumpai risiko strok lebih tinggi bermakna pada penderita dengan hiperinsulinemia pasca-makan (odds 2,89 95\% CI 1,14-7,40,p < 0,05) dan hiperinsulinemia puasa dan/atau pasca-makan (2,22 95\% CI 1,03 - 5,32, p <0,05) dibanding kelola. Disimpulkan bahwa pada penderita strok walaupun tanpa disertai diabetes melitus, telah dijumpai hiperinsulinemia pasca-makan. Hiperinsulinemia ini mungkin disebabkan oleh resistensi insulin dan berkaitan dengan hipertensi dan kolesterol-HDL yang rendah.
\end{abstract}

\begin{abstract}
To determine the presence of hyperinsulinemia in the absence of diabetes mellitus, a case-control study was carried out at the Out-Patient Clinic, Department of Neurology, Sardjito General Hospital, Yogyakarta, Indonesia. Patients included in the study were those who survived from stroke at least 3 months. Controls were selected from non-stroke patients at the same clinic with matching for sex and age. During the study 51 stroke patients $(39 \mathrm{M}, 12 \mathrm{~F}$, age $58.73 \pm 10.37$ years) and 51 controls $(39 \mathrm{M}, 12 \mathrm{~F}$, age $58.67 \pm 9.97$ years) were included. There was no significant difference of BMI (body mass index), smoking, and lipids except HDL-cholesterol levels between patients and controls. A significant reduced HDL-cholesterol concentrations $(46.69 \pm 16.05 v s 53.67 \pm 23.26 \mathrm{mg} / \mathrm{dl}$, $p<0.05)$ and significant higher BP (blood pressure) both systolic ( $160.50 \pm 24.86 \mathrm{vs} 131.30 \pm 11.78 \mathrm{mmHg}, p<0.05)$ and diastolic (101.30 \pm $13.03 \mathrm{vs} 79.90 \pm 4.74 \mathrm{mmHg}, p<0.05)$ were found in patients as compared to controls. Although there was no significant difference of fasting insulin levels $(9.28 \pm 2.74$ us $8.38 \pm 2.69 \mu \mathrm{U} / \mathrm{ml}, p>0.05)$, however, a significant increase of post prandial insulin levels $(94.89$ \pm 12.15 vs $55.21 \pm 6.88 \mu \mathrm{U} / \mathrm{ml}, p<0.05$ ) were found in patients as compared to controls. Although there was no significant difference of fasting insulin level both in NGT (normal glucose tolerance) and IGT (impaired glucose tolerance) subgroups, $p>0.05$, however, there was a significant increase of post-prandial insulin levels both in NGT $(98.15 \pm 14.97 \mathrm{vs} 38.76 \pm 6.62 \mu U / \mathrm{ml}, p<0.05)$ and IGT $(89.85 \pm 20.98 v \mathrm{vs} 75.24 \pm 11.82 \mu \mathrm{U} / \mathrm{ml}, p<0.05)$ subgroups in patients as compared to controls. There was significant increase of risk of stroke in patients with postprandial hyperinsulinemia (odds $2.8995 \%$ CI 1.14 to $7.40, p<0.05$ ) and fasting and/or post-prandial hyperinsulinemia $(2.2295 \%$ CI 1.03 to 5.32, p < 0.05) compared to controls. In conclusion, although there was no diabetes mellitus in stroke patients, postprandial hyperinsulinemia was found. The hyperinsulinemia may be due to insulin resistance and associated with hypertension and reduced HDL-cholesterol concentrations.
\end{abstract}

Keywords : non-diabetic stroke, hyperinsulinemia, hypertension, reduced HDL-cholesterol

Diabetes is a major risk factor of stroke. ${ }^{1}$ Hyperinsulinemia is responsible in the genesis of impaired

Department of Medicine, Medical Faculty, Gadjah Mada University/Dr. Sardjito General Hospital, Yogyakarta, Indonesia glucose tolerance (IGT), dyslipidemia, central obesity, and hypertension, i.e. abnormalities which are frequently found in type- 2 diabetes mellitus. ${ }^{2}$ Those abnormalities are called deadly quartet which is responsible for a majority of atherosclerotic diseases including cerebrovascular disease. ${ }^{3-5}$ Modan et al. 
reported that hyperinsulinemia was associated with excess cardiovascular disease in men and this risk was confined to hyperinsulinemic individuals in the presence of IGT, obesity, or hypertension. ${ }^{6}$ Essential hypertension is also associated with insulin resistance, independently of obesity and IGT. ${ }^{7}$

Therefore, question arises whether stroke patients had hyperinsulinemia in the absence of diabetes mellitus. The present study was aimed at determining the presence of hyperinsulinemia in stroke patients who had no diabetes mellitus.

\section{METHODS}

A case control study was done at the Out-Patient Clinic of the Department of Neurology, Sardjito General Hospital from December 1993 to May 1994. Patients recruited in this study were post-stroke patients who survived from stroke and evaluated 3 months or more after the attack and regularly visited the Out-Patient Clinic. Criteria for exclusion were laboratory evidence and/or family history of diabetes mellitus, renal failure, malignant disease, heart failure, myocardial infarction, those receiving treatment with hypolipidemic agents, and those receiving antihypertensive treatment. Diagnosis of stroke was established on a clinical basis with CT-Scan examination. Controls were selected from non-stroke patients who also regularly visited the same clinic with matching for sex and age.

Patients and controls who were eligible underwent physical examination including blood pressure (BP) and body mass index (BMI). Blood samples were taken for examination of blood sugar levels, insulin levels, lipids including total-cholesterol, HDL-cholesterol, LDL-cholesterol, and triglyceride concentrations. Insulin levels were determined by radioimmunoassay using Coat-A- Count kits. Lipid levels were determined by high performance spectrophotometry (Abbott).

Using 75 percentile of 46 non-obese and normal glucose tolerance individuals, hyperinsulinemia was defined as fasting insulin levels above $6.53 \mu \mathrm{U} / \mathrm{ml}$ and 2 hours post-prandial insulin levels above $72.49 \mu \mathrm{U} / \mathrm{ml}$. IGT was defined according to the WHO criteria (1985), namely fasting blood sugar levels less than $140 \mathrm{mg} / \mathrm{dl}$ and 2 hours post-prandial blood sugar levels (after 75 $\mathrm{mg}$ oral glucose load) between $140-200 \mathrm{mg} / \mathrm{dl} .^{8}$

Using exposed controls in population (po) 0.25 , odds ratio (OR) 3 , alpha 0.05 , and beta 0,2 by Schlesselman formula (1982), sample size was 50 samples each group. Data were presented as mean and standard deviation or proportion. Difference of means of vari- ables between case and control group were tested by student's $t$ test and difference of proportions were tested by chi square test. The difference between mean of variables also presented as $95 \%$ confidence interval.

\section{RESULTS}

During the study 51 patients ( 39 males and 12 females) aged $58.73 \pm 10.37$ years and 51 controls ( 39 males and 12 females) aged $58.67 \pm 9.87$ years were recruited. There was no statistical difference of the age between the two groups $(p>0.05)$. There was also no significant difference of BMI $(22.57 \pm 3.54$ vs $22.64 \pm 4.11 \mathrm{~kg} / \mathrm{m} 2$, $\mathrm{p}>0.05)$ and smoking (23/51 vs $20 / 51, \mathrm{p}>0.05)$ between the two groups. There was a significant higher blood pressure both systolic $(160.50 \pm 24 / 86 \mathrm{mmHg}$ vs $131.30 \pm 11.78 \mathrm{mmHg}, \mathrm{p}<0.05)$ and diastolic $(101.13 .03 \pm 13.03 \mathrm{mmHg}$ vs $79.90 \pm 4.72 \mathrm{mmHg}$, $\mathrm{p}<0.05$ ) of patients as compared to controls, and significant lower HDL- cholesterol concentrations $(46.69 \pm 16.65 \mathrm{mg} / \mathrm{dl}$ vs $53.67 \pm 23.26 \mathrm{mg} / \mathrm{dl}, \mathrm{p}<0.05)$ of patients as compared to controls. There were no significant differences of total-cholesterol, triglyceride, LDL- cholesterol, fasting and postprandial blood sugar levels of both groups ( $p>0.05$ ), see tabel 1 .

There was no significant difference of fasting insulin levels $(9.28 \pm 2.74 \mu \mathrm{U} / \mathrm{mL}$ vs $8 / 38 \pm 2.69 \mu \mathrm{U} / \mathrm{L}, \mathrm{p}>0.05)$ between patients and controls. However, significant higher post-prandial insulin levels $(94.89 \pm 12.15$ $\mu \mathrm{U} / \mathrm{mL}$ vs $55.21 \pm 6.88 \mu \mathrm{U} / \mathrm{mL}, \mathrm{p}<0.05$ ) were found in patients as compared to controls. See table 2 .

Both patients and controls were devided into normoglucose tolerance (NGT) (patients 31, controls, 28) and impaired glucose tolerance (IGT) (patients 20, controls, 23) subgroups to look at the possibility of insulin secretion response after glucoce loads in both groups. It was found that insulin levels were significantly increased only after glucose load (2 hours postprandial) both in the NGT subgroup ( $98.15 \pm 14.97$ $\mu \mathrm{U} / \mathrm{mL}$ vs $38.76 \pm 6.62 \mu \mathrm{U} / \mathrm{mL}, \mathrm{p}<0.05)$ and in the IGT subgroup $(89.85 \pm 20.98 \mu \mathrm{U} / \mathrm{mL}$ vs $75.24 \pm 11.82$ $\mu \mathrm{U} / \mathrm{mL}, \mathrm{p}<0.05)$ in patients as compared to controls. However, there was no significant difference of fasting insulin levels in NGT subgroup $(7.15 \pm 1.31 \mu \mathrm{U} / \mathrm{mL}$ vs $6.08 \pm 1.30 \mu \mathrm{U} / \mathrm{mL}, \mathrm{p}>0.05)$ and IGT subgroup $(12.56 \pm 6.74 \mu \mathrm{U} / \mathrm{mL}$ vs $11.18 \pm 5.78 \mu \mathrm{U} / \mathrm{mL}, \mathrm{p}>0.05)$ between patients and controls.

There was a significant increased risk of stroke in patients with postprandial hyperinsulinemia ( $47.1 \%$ vs $23.5 \%$, odds $2.89, \mathrm{p}<0.05$ ) and fasting and/or postprandial hyperinsulinemia patients $(62.7 \%$ vs $43.1 \%$, odds $2.22, \mathrm{p}<0.05$ ) as compared to controls. 
Table 1. Clinical characteristics of stroke patients and controls

\begin{tabular}{|c|c|c|c|}
\hline Characteristics & $\begin{array}{c}\text { Stroke Patients } \\
\quad \mathrm{n}=51\end{array}$ & $\begin{array}{c}\text { Controls } \\
\mathrm{n}=51\end{array}$ & $\begin{array}{c}\text { P value } \\
(\mathrm{MD} 95 \% \mathrm{CI})^{*}\end{array}$ \\
\hline Age (years) & $58.73 \pm 10.37$ & $58.67 \pm 9.87$ & $\begin{array}{c}0.3648 \\
(-3.86 \text { to } 3.98)\end{array}$ \\
\hline 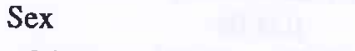 & & & \\
\hline Males & 39 & 39 & \\
\hline Females & 12 & 12 & \\
\hline BMI $(\mathrm{kg} / \mathrm{m} 2)$ & $22.57 \pm 3.56$ & $22.64 \pm 4.11$ & $\begin{array}{c}0.8127 \\
(-1.56 \text { to } 1.42)\end{array}$ \\
\hline \multicolumn{4}{|l|}{ Blood pressure } \\
\hline Systolic (mm Hg) & $160.50 \pm 24.56$ & $131.30 \pm 11.78$ & $\begin{array}{c}0.0000 \\
(21.66 \text { to } 36.74)\end{array}$ \\
\hline Diastolic (mm Hg) & $101.30 \pm 13.03$ & $79.90 \pm 4.74$ & $\begin{array}{c}0.0000 \\
(17.60 \text { to } 25.20)\end{array}$ \\
\hline Smoking & 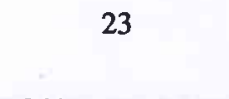 & 20 & $\begin{array}{c}0.5475 \\
(-10.71 \text { to } 2.52)\end{array}$ \\
\hline Total-cholesterol (mg/dl) & $241.30 \pm 40.24$ & $218.40 \pm 44.82$ & $\begin{array}{c}0.2240 \\
(-12.52 \text { to } 4.32)\end{array}$ \\
\hline LDL-cholesterol (mg/dl) & $134.90 \pm 44.12$ & $140.50 \pm 36.38$ & $\begin{array}{c}0.0879 \\
(-13,60 \text { to } 2.40)\end{array}$ \\
\hline HDL-cholesterol (mg/dl) & $46.69 \pm 16.05$ & $53.67 \pm 23.26$ & $\begin{array}{c}0.004 \\
(-12.10 \text { to }-1.95)\end{array}$ \\
\hline Triglyceride (mg/dl) & $169.90 \pm 61.85$ & $141.00 \pm 60.51$ & $\begin{array}{c}0.4390 \\
(-4.26 \text { to } 51.74)\end{array}$ \\
\hline $\begin{array}{l}\text { Blood sugar } \\
\text { fasting }(\mathrm{mg} / \mathrm{dl})\end{array}$ & $76.16 \pm 13.10$ & $79.59 \pm 21.16$ & $\begin{array}{c}0.8695 \\
(-6.23 \text { to } 5.37)\end{array}$ \\
\hline postprandial (mg/dl) & $131.20 \pm 33.69$ & $133.00 \pm 36.32$ & $\begin{array}{c}0.2983 \\
(-12.71 \text { to } 9.40)\end{array}$ \\
\hline
\end{tabular}

${ }^{*}$ Mean of difference $95 \%$ confidence interval

Table 2. Insulin levels in stroke patients and controls

\begin{tabular}{lccc}
\hline & Patients & Controls & $\begin{array}{c}\text { P value } \\
\text { (MD 95\% CI) }\end{array}$ \\
\hline $\begin{array}{l}\text { Fasting insulin } \\
(\mu \mathrm{U} / \mathrm{mL})\end{array}$ & $9.28 \pm 2.74$ & $8.38 \pm 2.69$ & 0.4485 \\
$\begin{array}{l}\text { Postprandial } \\
\text { insulin }(\mu \mathrm{U} / \mathrm{mL})\end{array}$ & $94.89 \pm 12.15$ & $55.21 \pm 6.88$ & $(-6.44$ to 8.64$)$ \\
\hline
\end{tabular}

* Mean of difference $95 \%$ confidence interval 
Table 3. Insulin levels in normal glucoce tolerance (NGT) and impaired glucose tolerance (IGT) subgroup in stroke patients and controls

\begin{tabular}{lccc}
\hline & Patients & Controls & $\begin{array}{c}\text { P value } \\
(\mathrm{MD} 95 \% \mathrm{CI})^{*}\end{array}$ \\
\hline $\begin{array}{l}\text { NGT } \\
\text { fasting insulin }(\mu \mathrm{U} \pm \mathrm{ML})\end{array}$ & $\mathrm{n}=31$ & $\mathrm{n}=28$ & 0.3841 \\
& $7.15 \pm 1.31$ & $6.08 \pm 1.30$ & $(-2.23$ to 4.60$)$ \\
postprandial insulin $(\mu \mathrm{U} / \mathrm{mL})$ & & 0.0008 \\
& $98.15 \pm 14.97$ & $38.76 \pm 6.62$ & $(46.56$ to 97.24$)$ \\
IGT & $\mathrm{n}=20$ & $\mathrm{n}=23$ & 0.3508 \\
fasting insulin $(\mu \mathrm{U} / \mathrm{mL})$ & $12.58 \pm 6.74$ & $11.18 \pm 5.78$ & $(-25.98$ to 18.78$)$ \\
postprandial insulin $(\mu \mathrm{U} / \mathrm{mL})$ & $89.85 \pm 20.98$ & $75.24 \pm 11.82$ & 0.0125 \\
& & & $(5.31$ to 25.53$)$ \\
\hline
\end{tabular}

* difference of mean $95 \%$ confidence interval

Table 4. Risk of stroke in hypersulinemic stroke patients and controls

\begin{tabular}{|c|c|c|c|c|}
\hline Hyperinsulinemia & Patients & Controls & $\begin{array}{c}\text { Odds } \\
(95 \% \mathrm{CI})\end{array}$ & P value \\
\hline Fasting ${ }^{*}$ & $14(27.5 \%)$ & $16(31.4 \%)$ & $\begin{array}{c}0.83 \\
(-0.32 \text { to } 2.11)\end{array}$ & 0.6650 \\
\hline Postprandial $^{* *}$ & $24(47.1 \%)$ & $12(23.5 \%)$ & $\begin{array}{c}2.89 \\
(1.14 \text { to } 7.40)\end{array}$ & 0.0130 \\
\hline Fasting and/or postprandial & $32(62.7 \%)$ & $22(43.1 \%)$ & $\begin{array}{c}2.22 \\
(1.03 \text { to } 5.32)\end{array}$ & 0.0480 \\
\hline
\end{tabular}

* cut-off value of $6.53 \mathrm{mU} / \mathrm{ml}$

** cut-off value of $72.49 \mathrm{mU} / \mathrm{ml}$

\section{DISCUSSION}

The present study showed that some cardiovascular risks existed in stroke patients. Those risks factors were hypertension, dyslipidemia, namely reduced HDL-cholesterol concentrations shown by their significant abnormality as compared to controls $(p<0.05)$. However, no significant difference was found for some other risk factors namely obesity and smoking as shown on table 1. Regarding to glucose metabolism, although diabetes mellitus as defined by the definition of WHO (1985) has already been excluded from the study, it showed that some abnormalities were found in this study. The abnormalities were higher increase of insulin response after glucoce load in patients as compared to controls $(p<0.05)$. Even the increase of insulin levels in patients also occurred both in the NGT subgroup and IGT subgroup as compared to controls $(\mathrm{p}<0.05)$. This maybe interpreted as although there was no clinical and laboratory evidence of diabetes mellitus, the abnormal insulin resistance or pre-clinical diabetes mellitus already existed in stroke patients. In addition, hyperinsulinemia was significantly higher in patients both postprandially and fasting and/or postprandially $(\mathrm{p}<0.05)$. Modan et al. found that hyperinsulinemia was associated with excess CVD risk in men (risk ratio $2.27,95 \% \mathrm{Cl} 1.33$ to 3.08 ) but not in women (risk ratio $0.85,95 \% \mathrm{CI} 0.48$ to 1.49 ), in the presence of GOH (impaired glucose tolerance, obesity and hypertension). ${ }^{6}$ Our study has shown that there is an increased risk ratio of stroke in the subgroup of patients with postprandial (risk ratio $2.8995 \%$ CI 1.14 to $7.40, p<0.05$ ) and in the subgroup of patients with only fasting and/or postprandial hyperinsulinemia (risk ratio $2.22,95 \% \mathrm{CI} 1.03$ to $5.32, \mathrm{p}<0.05$ ), but not in the subgroup of patients with fasting hyperinsulinemia (risk ratio $0.83,95 \% \mathrm{CI}-0.32$ to 2.11 , $\mathrm{p}>0.05$ ). Although the present study did not describe 
the sex difference on the risk of stroke in hyperinsulinemic patients, it seemed that all rates of stroke risk ratio in postprandial hyperinsulinemic patients were similar with those found by Modan et al. in men. Hyperinsulinemia in our series may also explain the presence of dyslipidemia and hypertension. Two studies showed the evidence associating elevated insulin levels with increased risk of ischemic heart disease (IHD) morbidity and mortality, ${ }^{10 ! 1}$, as well as, with overall CVD mortality. ${ }^{10}$ These studies showed that elevated insulin levels predict the risk of IHD and CVD mortality. A study by Cullen et al., however, showed that elevated insulin levels were predictive of CVD only in men, the results of which were similar to those found by Modan et al. Our study, however, did not take into account sex as a risk of CVD in association with hyperinsulinemia. Our study showed that patients with stroke had higher blood pressure both systolic and diastolic and reduced HDL-cholesterol levels. It was shown that insulin resistance is directly correlated with the severity of hypertension in patients with essential hypertension. ${ }^{7}$ and patients with hypertension had 2 to 4,8 greater riks to have intracerebral hemorrhage than normotensive controls. ${ }^{12,13}$ It was still to be determined, however, whether hypertension and dyslipidemia are associated with hyperinsulinemia in our series or whether hyperinsulinemia is an independent risk factor of stroke. Reaven described the association of hyperinsulinemia with hypertension and dyslipidemia. ${ }^{14}$ Kannel showed an association of cholesterol levels and the risk of stroke particularly in non-hemorrhagic stroke. ${ }^{15}$ It was believed that insulin resistance in association with hypertension and dyslipidemia may produce atherosclerosis in cerebral vessels through direct insulin action on the vessel wall and through secondary metabolic substance..$^{4,16}$

In conclusion, this study showed that although diabetes mellitus was already excluded in stroke patients, postprandial hyperinsulinemia still exists. The hyperinsulinemia may be due to insulin resistance and associated with hypertension and reduced HDLcholesterol concentration which co-exist in the patients. Further study is needed to elucidate whether hypertension and dyslipidemia are associated with hyperinsulinemia in these patients.

\section{REFERENCES}

1. Kannel WB, McGee DL. Diabetes and cardiovascular risk factors; Framingham Study. Circulation 1979; 59:8-13

2. Reaven GM. Role of insulin resistance in human disease. Diabetes 1988;37:1590-606.

3. Kaplan NM : The deadly quartet, upper body obesity, glucose intolerance, hypertriglyceridemia, and hypertension. Arch Intern Med 1989;149:1514-20.

4. Stout RW. Overview of the association betweem insulin and atherosclerosis. Metabolism 1985;34:7-12.

5. DeFronzo RA, Ferrannini E. Insulin resistance and multifacet syndrome responsible for NIDDM, obesity, hypertension, dyslipidemia, and atherosclerosis cardiovascular disease. Diabetes Care 1991;14:173-94.

6. Modan M, Or J, Karasik A, Drory Y, Fusch Z, Lusky A, et al. Hyperinsulinemia, sex and risk of atherosclerotic cardiovascular disease. Circulation 1991;84:1165-75.

7. Ferrannini E, Buzzigoli G, Bonadonna R, Giorico MA, Oliggeni M, Grazidei $L$, et al. Insulin resistance in essential hypertension N Engl J Med 1987;317:350-7.

8. WHO. Diabetes mellitus. Report of WHO study group. WHO techn. Rep. Ser. 727, 1985.

9. Schelesselman JJ. Case control studies, design, conduct, analysis. New York : Oxford University Press. 1982; 160-2.

10. Cullen K, Stenhous, NS, Weame KL, Welborn TA. Multiple regression analysis of risk factors for cardiovascular disease and cancer mortality in Busseltown, Western Australia-13 year study. J Chronic Dis 1983;36:371-7.

11. Pyorala K, Savolainen E, Kaukola S, Haapakoski J. Plasma insulin as coronary disease risk factor : relationship to other risk factors and predictive value during $91 / 2$ years follow-up of the Helsinki Policeman study population. Acta Med Scand 1985;701 (suppl):38-52.

12. Calandre L, Arnal C, Ortega JF, Bermejo F, Felgeroso G, Delser $T$, et al. Risk Factors for spontaneous cerebral hematomas. Case control study. Stroke 1986;17:1126-8.

13. Herman B, Schmitz IM, Leyten CM. Multivariate logistic analysis of risk factors for stroke in Tilburg, the Netherlands. Am J Epidemiol 1983;118:514-25.

14. Reaven GM : Role of abnormalities of carbohydrate and lipoprotein metabolism in the pathogenesis and clinical course of hypertension. J Cardiovas Pharmacol 1990;15 (suppl 5):S4.

15. Kannel WB. Lipids, diabetes, and coronary heart disease: insight from the Framingham study. Am Heart J 1985; 110:1100.

16. Stout RW. Insulin and atherosclerosis : an update. Lancet 1987;1077-9. 